\title{
Anti-EU and Anti-LGBT Attitudes in Poland: Considering Quantitative and Qualitative Evidence
}

\author{
Joanna Chojnicka \\ Faculty of Linguistics and Literary Studies \\ University of Bremen and \\ Leuphana University Lüneburg, \\ Germany \\ E-mail: joanna.chojnicka@leuphana.de
}

Abstract: The purpose of this study is to investigate anti-EU and antiLGBT attitudes in Poland on the basis of quantitative evidence (statistical data) and qualitative evidence (discourse analysis of statements expressed on the Internet). As Euroscepticism seems to frequently appear in conjunction with prejudice against LGBT (lesbian, gay, bisexual and transsexual or transgender) persons, the task of this article is to find out whether they may have a common foundation and what it may be.

A possible answer, as the article argues, is that both attitudes could be considered symptoms of a deeper, more wide-ranging and fundamental problem-a fear, tension, or anxiety caused by social change, especially the fragmentation of dominant collective (national) identity. The case for such an interpretation of the situation is first made on the basis of existing academic literature and statistical data provided by Eurobarometer and the Polish Public Opinion Research Centre (Centrum Badania Opinii Społecznej, CBOS). However, as the text further argues, such quantitative methods have their limitations and should be supported and illustrated with qualitative studies. The article thus proposes an alternative discourse-oriented approach, namely critical discourse analysis (CDA). This approach is used to conduct an introductory, presentational analysis of some examples of anti-EU and anti-LGBT discourse found on the Internet.

This analysis shows that sexual minorities represent values so strange and foreign to Polish conservatives that they can only be conceptualized as something imposed by the power which is both new 
and distant-by Brussels. And the other way round, the European Union's liberalism and espousal of human rights, including women's and LGBT rights, makes it impossible for the conservative parts of the Polish society to accept a "European identity". This means that Euroscepticism and LGBT prejudice are not just occasionally, coincidentally connected expressions of an underlying resistance to change, but that a closer relationship exists between them. Namely, the conservative reluctance or hostility towards both the EU and $L G B T$ is caused by their incompatibility with the patriotic and religious national identity construction.

Keywords: discourse analysis, Euroscepticism, homophobia, patriotism, Poland

\section{Introduction}

After the Soviet Union collapsed and Poland transitioned to the democratic system, it was self-evident that the country would only take the path leading to membership in the European Union and NATO. The metaphor of seeking to "return to Europe" became the guiding principle of post-socialist transition, and Poland was considered one of the most Euro-enthusiastic countries (Cichocki, 2011; Mole, 2012). The envisioned membership in the EU was a matter of national pride as much as of pragmatic necessity: hidden for so long behind the Iron Curtain, Poles detested, and still detest, being associated with "the East". The idea of being located on the periphery instead of in the centre of historical events was hard to accept: "the return to Europe was, in this context, supposed to denote a return to the path of modernization, understood as westernization" (Cichocki, 2011, p. 266).

Before the European Union membership referendum took place in Poland in 2003, the pro-Union stance had been adopted and advocated by the majority of political parties. The EU membership was protested only by Liga Polskich Rodzin ('The League of Polish Families'), Samoobrona Rzeczpospolitej Polskiej ('Self-Defence of the Republic of Poland') and Unia Polityki Realnej ('Real Politics Union'). The outcome of the vote was convincingly positive (see Table 1).

Even in the current climate of Euroscepticism rising across the Union, Poland remains at the forefront of supporters of European integration. Still, the results of the recent elections to the European Parliament (2014), in which the Eurosceptic Congress of the New Right received four seats, may herald a possible change. 
Taking into account Poland's strategic location and relatively large population, it is never too early to address the issues of reasons and possible outcomes of the decline of its support for the European project.

\section{Table 1. Results of EU membership referendums in Poland in 2003, \%}

\begin{tabular}{|c|c|}
\hline Turnout $-\%$ of people entitled to vote & 58.85 \\
\hline 'Yes' votes & 77.45 \\
\hline 'No' votes & 22.55 \\
\hline Invalid votes & 0.72 \\
\hline
\end{tabular}

In the present article, the Eurosceptic attitude shall be considered in conjunction with prejudice against LGBT (lesbian, gay, bisexual and transsexual or transgender) persons, arguing that they are both symptoms of a deeper, more wide-ranging and fundamental problem - a "cultural anxiety associated with a change in the collective identity" (Graff, 2010, p. 125). Strong conservative resistance towards feminist and gay/lesbian-increasingly conceptualized as gender and queer-movements in Poland reflects an almost fanatical attachment to the world of clear-cut, mutually exclusive and unchangeable identities provided "from above". At the same time, the European Union's liberalism and espousal of human rights, including women's and LGBT rights, makes it impossible for the conservative parts of the Polish society to accept the "European identity", however convincingly it may be promoted in public discourse (cf. Magistro, 2007; Caliendo \& Magistro, 2009).

The article is structured as follows. First, in Section 2, quantitative evidence of anti-EU (2.1-2.2) and anti-LGBT (2.3-2.4) attitudes in Poland coming from the existing scientific literature and statistical data is presented and analyzed. Next, in response to the limitations of quantitative methods discussed in Section 3.1, the article provides illustrative and supportive qualitative evidence of these attitudes on the basis of examples of conservative Polish Internet discourse, adopting the theoretical and methodological framework of critical discourse analysis (CDA), along the lines of van Dijk $(1983 ; 1993)$ and Wodak (2002) (see Section 3.2 below). Combining quantitative and qualitative perspectives in Section 4 shows that Euroscepticism and LGBT prejudice are not just occasionally, coincidentally connected expressions of an underlying resistance to change, but that a closer relationship exists between them. Namely, as Section 5 ('Discussion and conclusion') suggests, the conservative reluctance or hostility towards both the EU and LGBT may be caused by their incompatibility with national identity, constructed on the basis of patriotism and (Catholic) religion. 


\section{Quantitative evidence}

\subsection{Euroscepticism in Poland: the data}

In order to trace attitudes towards the European Union since the accession in 2004, results of Eurobarometer surveys from autumn 2004 to autumn 2013 (EC, 2004-EC, 2013b) have been compared. This approach has required finding the same questions concerning citizens' positions towards their country's membership in 19 reports. Unfortunately, only one such question has been found, asking respondents about their level of trust in the EU as an institution. The possible answers are: 'tend to trust', 'tend not to trust', 'don't know'. Although it seems equally important to identify all results for all the answers - as a negative answer is at least as informative as a positive onesome Eurobarometer reports mention only the results for the positive answer, rendering their comparative potential incomplete. All the available answers are brought together in Table 2.

As shown, positive answers have prevailed over negative ones in all but two reports, and never fell under 50 per cent until Eurobarometer 76 (EC, 2011b). And even if they are now gradually decreasing, it is a trend common to the entire Union. Notably, the Polish results have always been higher than the EU average (after taking off from the same position of $50 \%$ in EC, 2004).

Another question relevant to this study is: 'Generally speaking, do you think that [our country]'s membership of the European Union is...?' with the possible answers: 'a good thing', 'a bad thing', 'neither good nor bad', 'don't know'. Unfortunately, for reasons that could be quite revealing, this question was dropped and has not appeared since Eurobarometer 73 (EC, 2010a). According to the results for this question, support for the European Union in Poland after the accession was steadily growing, reaching its peak in autumn 2007, when 71 per cent of respondents claimed that EU membership was a good thing. A slight decrease in support followed, but it never fell below 60 per cent. Thus, Poland has always scored high on the 'a good thing' answer and low on the 'a bad thing' answer. Also, Polish scores have been consistently higher than the EU average since Eurobarometer 64 (EC, 2005b). 
Table 2. Answers to the question concerning trust in the European Union in Eurobarometers 62-80 (EC, 2004-EC, 2013b), \%

\begin{tabular}{|c|c|c|c|}
\cline { 2 - 4 } \multicolumn{1}{c|}{} & Tend to trust & $\begin{array}{c}\text { Tend not to } \\
\text { trust }\end{array}$ & Don't know \\
\hline Eurobarometer 62 & 50 & 27 & 23 \\
\hline Eurobarometer 63 & 52 & 31 & 17 \\
\hline Eurobarometer 64 & 51 & $\mathrm{n} / \mathrm{a}$ & $\mathrm{n} / \mathrm{a}$ \\
\hline Eurobarometer 65 & 58 & $\mathrm{n} / \mathrm{a}$ & $\mathrm{n} / \mathrm{a}$ \\
\hline Eurobarometer 66 & 58 & 26 & 17 \\
\hline Eurobarometer 67 & 68 & 18 & 14 \\
\hline Eurobarometer 68 & 62 & $\mathrm{n} / \mathrm{a}$ & $\mathrm{n} / \mathrm{a}$ \\
\hline Eurobarometer 69 & 59 & 22 & 19 \\
\hline Eurobarometer 70 & 55 & 28 & 17 \\
\hline Eurobarometer 71 & 52 & 31 & 17 \\
\hline Eurobarometer 72 & 52 & 29 & 19 \\
\hline Eurobarometer 73 & 52 & 35 & 13 \\
\hline Eurobarometer 74 & 58 & 29 & 13 \\
\hline Eurobarometer 75 & 52 & 33 & 15 \\
\hline Eurobarometer 76 & 47 & 41 & 12 \\
\hline Eurobarometer 77 & 41 & 46 & 13 \\
\hline Eurobarometer 78 & 48 & 42 & 10 \\
\hline Eurobarometer 79 & 39 & 51 & 10 \\
\hline Eurobarometer 80 & 45 & 39 & 16 \\
\hline
\end{tabular}

On the basis of these statistics alone, it would be difficult to talk about Euroscepticism in Poland. Still, Poland is on the list of countries raising concerns for this particular reason. For example, Torreblanca and Leonard write that

EU seems to have lost its reputation as the anchor of stability for a country undergoing a huge social and economic transformation. In particular, the Poles are sceptical about the future of the common currency and only 29 percent of them now wish to join it. (Torreblanca \& Leonard, 2013, p. 5)

In turn, Boros and Vasali list Poland in the group of countries "critical of the EU due to differences in policies", which

had serious confrontations with the EU on the policy level in the past years, but the social interpretation of these conflicts did not 
make the institutions in Brussels a "distant enemy". We can suppose that these countries view such tensions as necessary components of membership. (Boros \& Vasali, 2013, p. 9)

The authors mention abortion as such a bone of contention between Poland and the EU. Poland has one of the most restrictive anti-abortion laws in Europe. But this law, just like Polish homophobia, is merely one of the many displays of a "radically restrictive vision of gender and sexuality" conceptualized as one of the bases of national and religious belonging construction (Graff, 2010, p. 126), incompatible with the liberal and secular politics of Brussels.

Further on the nature of Polish Euroscepticism, Cichocki (2011, p. 271) agrees that it does not consist in questioning whether Poland should be in the EU in the first place - rather, it criticizes the ways in which the country is affected by its membership. Leaving the EU or supporting its dissolution is not a viable option (or at least was not, before the Congress of the New Right). The membership is rather considered as given, a point of departure for further action. He also observes "a complete lack of involvement in European matters" (Cichocki, 2011, p. 265), indicated, for example, by the alarmingly low voter turnout in EP elections in the country, as Table 3 illustrates.

Table 3. Voter turnout in European Parliament elections for Poland and the EU average, \%

\begin{tabular}{|c|c|c|}
\hline Year & EU average & Poland \\
\hline 2004 & 45 & 21 \\
\hline 2009 & 43 & 25 \\
\hline 2014 & 43 & 23 \\
\hline
\end{tabular}

\subsection{Euroscepticism in Poland: possible explanations}

This drastically low turnout, coupled with a literal lack of actual voices for leaving the EU, could signal a kind of resignation, acceptance of the status quo in spite of lack of belief in or attachment to it - something that Mishler and Pollack (2003) call 'apolitical privatism'. Many citizens socialized under communism developed a kind of dissociation from and indifference towards matters of the state, preferring to focus on the immediate and future needs of their families. As attitude change happens only slowly and gradually, "it is often difficult for the people in former Eastern bloc countries to accommodate to the newly introduced democratic, judicial, and economic institutions" (Mishler \& 
Pollack, 2003, p. 248). They accept the status quo, learn to live with it and adjust in case of any changes. In the context of this article, it may be interesting to mention this as one of the possible reasons accounting for the relatively low activism of Polish LGBT community. ${ }^{1}$

Apolitical privatism is connected with low trust in national-level institutions. According to Standard Eurobarometer Report 80, the total of 77 per cent and 76 per cent of Poles tend not to trust the parliament and government, respectively (trust is declared by 17 and 19 per cent, respectively). According to a Social Cohesion Radar (Bertelsmann Stiftung, 2013), which measured various dimensions of social life in Europe in four time periods (1989-1995, 19962003, 2004-2008, 2009-2012), trust in people, perception of fairness, and focus on the common good are also particularly low in Poland.

These weaknesses of communal life and the literal lack of civil society in Poland derive from de-structuration - "the kind of societal self-knowledge in which social groups and classes, despite their 'real' existence, do not perceive themselves in terms of common interest or a shared social identity" (Sidorenko, 2008, p. 115), inherited from the previous system. Not classes or interest groups, but rather the nation and the family are two primary sources of subjectivities in Poland (Sidorenko, 2008, p. 121). This "organic" notion of nationhood as an obligatory collective identity poses a threat to the acceptance of diversitycultural diversity and national solidarity are seen as mutually exclusive (Lindqvist, 2003, p. 313).

Low trust in people and institution reflects the prevalent atmosphere of a nation under threat:

Poland's status as a nation state has never been more secure. In the years since the collapse of communism, Polish independence has been reinforced by the anchoring of its security within the structures of NATO and by accession to the EU. However, despite these developments, much of public discourse in Poland continues to imply threats and crisis by focusing on patriotism, the need for moral education, and the cultivation of acceptable values. (Sidorenko, 2008, p. 109)

Additionally, low trust in institutions such as political parties is connected with party fragmentation and low institutionalization in Poland. Party membership is miniscule, their popularity often depends on the authority and charisma of their

1 For example, Polish gays have been called "lazy lemmings" that prefer to "sit in the closet instead of fighting for their rights" (Rient, n.d.). 
leaders, and they are distinguished on the basis of stance on particular issues rather than according to the left-centre-right division (O'Dwyer \& Schwartz, 2010).

These results support the picture of a country "politically unstable", "with corruption and low levels of social trust", with high "material and social insecurity", "with social dislocation producing an anxious population" (Sidorenko, 2008, p. 112). Polish democracy, which still has a lot to learn and is "emerging with difficulty" (Sidorenko, 2008, p. 112), is among those rated the lowest in the European Union.

In this light, I would argue that Polish Euroscepticism must be considered within a broader context of ambivalence, indifference and disconnection that characterize citizens' attitudes towards politics and political institutions at large. Often, negative attitudes to the European Union or national-level bodies are an expression of a more general dissatisfaction or anxiety, especially in the context of lack of financial/material stability.

\subsection{Prejudice against LGBT in Poland: the data}

It is relatively easy to find in the literature statements that condemn Poles as prejudiced against LGBT, such as "Poles are a nation of homophobes, and proud of it" (Graff, 2006, p. 449). Results of many surveys conducted both at national and international (European) level seem to substantiate this claim. Gruszczyńska (2007) reports that 86 per cent of Poles do not want their children to come in contact with gays or lesbians. The share of Poles who believe that homosexual acts between consenting adults should be illegal is 40 per cent, and about the same number would prefer not to have any contact with gays and lesbians at all. Finally, only 4 per cent believe that homosexuality is normal, and a further 55 per cent claim that it is a deviation from the norm that could be tolerated but should not be accepted (Gruszczyńska, 2007, p. 96).

The European Commission includes questions concerning discrimination against and attitudes towards sexual minorities in Standard and Special Eurobarometer surveys. The results of these surveys show a mixed picture. In 2006, the acceptance of (1) homosexual marriages and (2) adoption of children by homosexual couples in Poland was reported as much lower than the European average. The results were: (1) Poland-17\%, EU average- 44\%; (2) Poland-7\%, EU average-32\% (EC, 2006b). 
Poland also scores high on the perception of discrimination on the basis of sexual orientation:

Table 4. Is discrimination on the basis of sexual orientation widespread in your country?' (2007, 2008 and 2012), \%

\begin{tabular}{|c|c|c|}
\hline Special Eurobarometer survey & Poland & EU average \\
\hline 2007 & 59 & 50 \\
\hline 2008 & 52 & 51 \\
\hline 2012 & 42 & 46 \\
\hline
\end{tabular}

The Polish Public Opinion Research Centre (Centrum Badania Opinii Spolecznej, CBOS) conducts surveys on public attitudes towards sexual minorities in Poland. Their reports from 2001, 2003, 2005, 2008, 2010 and 2013 have been analyzed for this study. The questions asked in these surveys have not always been the same, but most of them have appeared in at least three reports, which makes it possible to trace the development of certain attitudes over time.

Table 5a. Attitudes on LGBT persons' public rights in Poland, \%

\begin{tabular}{|c|c|c|c|}
\hline & Yes & No & Don't know \\
\hline \multicolumn{4}{|c|}{ Right to show their lifestyle in public } \\
\hline 2005 & 16 & 78 & 6 \\
\hline 2008 & 25 & 69 & 6 \\
\hline 2010 & 29 & 64 & 7 \\
\hline 2013 & 30 & 63 & 7 \\
\hline \multicolumn{4}{|c|}{ Right to organize manifestations } \\
\hline 2005 & 20 & 74 & 6 \\
\hline 2008 & 27 & 66 & 7 \\
\hline 2010 & 30 & 64 & 6 \\
\hline
\end{tabular}

Table 5a above indicates a very slow but consistent increase in the acceptance of LGBT persons' public rights. On the other hand, the acceptance of private rights has not changed much since 2001 (see Table 5b). 
Table 5b. Attitudes on LGBT persons' private rights in Poland, \%

\begin{tabular}{|c|c|c|c|}
\hline & Yes & No & Don't know \\
\hline \multicolumn{4}{|c|}{ Right to legalization of relationships } \\
\hline 2003 & 34 & 56 & 10 \\
\hline 2005 & 46 & 44 & 10 \\
\hline 2008 & 41 & 48 & 11 \\
\hline 2010 & 45 & 47 & 8 \\
\hline \multicolumn{4}{|c|}{ Right to adoption of children } \\
\hline 2001 & 8 & 84 & 8 \\
\hline 2003 & 8 & 84 & 8 \\
\hline 2005 & 6 & 90 & 4 \\
\hline 2008 & 6 & 90 & 4 \\
\hline 2010 & 6 & 89 & 5 \\
\hline 2013 & 8 & 87 & 5 \\
\hline \multicolumn{5}{|c|}{ Right to sexual intercourse in a relationship } \\
\hline 2001 & 40 & 42 & 18 \\
\hline 2003 & 38 & 36 & 26 \\
\hline 2005 & 40 & 42 & 18 \\
\hline 2008 & 37 & 37 & 26 \\
\hline 2010 & 42 & 37 & 21 \\
\hline
\end{tabular}

\subsection{Prejudice against LGBT in Poland: possible explanations}

O'Dwyer and Schwartz (2010, p. 222) list three important variables that shape the negative attitudes towards LGBT in Poland: (1) religion, (2) national identity and (3) party system institutionalization.

Religion. Poland is a predominantly Catholic country - 91 per cent of Poles identified themselves as Catholic in 2012 (EC, 2012c). Catholicism is a significant part of what it means to be a Pole: the Catholic Church is the source of collective rituals and narratives forming and sustaining national identity (Marody \& Mandes, 2005); to identify with Poland is to identify with its Church (McManus-Czubińska \& Miller, 2008, p. 132) and disagreeing with its teachings makes one somewhat less Polish (Selinger, 2008). These teachings include an anti-gay stance: the Catholic Church is traditionally hostile to sexual minorities. To compare, in the neighbouring country of Lithuania, where Catholicism constitutes an equally important part of the national narrative (Schröder, 2009), 
"the Church is more active than ever in pushing an archconservative social agenda" (Duvold \& Aalia, 2012, p. 42), blocking any debate on LGBT rights.

It is often mentioned that the Church has such a high moral, cultural and political position in Poland because of the role it played in independence and democratization movements in the 1980s and 1990s. Although in those days it embraced the ideals of freedom, equality and human rights, after the transition it turned against the further emancipation of, inter alia, women and sexual minorities (Abramowicz, 2010, p. 110). Indeed, following an era of women's strong presence on the job market under the previous system, the Church and the conservative elites are now trying to force them "back into the kitchen" (Fodor $\&$ Balogh, 2010) and bemoan the current "crisis of the family" and "crisis of masculinity" heralded by the gender and queer movements (Graff, 2010). We are once again reminded of a link between the situation of women and LGBT, already mentioned in relation to the restrictive vision of gender and sexuality (see Section 2.1).

National identity. The conservative right-wing discourse in Poland elevates the nation to an almost sacred position, rendering the individual as always inferior to the nation (Sidorenko, 2008, p. 117) and matters of personal happiness insignificant when compared to the needs of the nation (Mole, 2012, p. 86). Note that in such nationalistic discourses, the perception of women is highly problematized. On the one hand, they occupy a high position of the idealized Mother - maternity is held sacred and considered the only legitimate realization of femininity (Adamiak \& Sobkowiak, 2011, p. 10). On the other hand, women are a liability - always at risk of rape and defilement, they symbolize the nation's vulnerability (Mostov, 2000, p. 98). This is important for the position of LGBT not only because it renders lesbians especially unacceptable, but also because the level of discrimination of homosexual men is always linked with the position of women in a society. The more patriarchal it is, the more are the men not fitting the image of "real masculinity" ridiculed and humiliated (Abramowicz, 2010, p. 108). All these statements point to an organic connection between religion, family and nation in Poland.

Party system institutionalization. Low party institutionalization means that political parties do not have a loyal electorate but must compete for votes from elections to elections. Under these conditions, left-wing parties (which are drastically weak in Poland anyway) find it too risky to embrace issues of the civil rights of LGBT persons. Furthermore, such a setting promotes populist political discourse, appealing especially to the will and needs of the common people and families, and to traditional and religious values. The most Eurosceptic Polish 
political parties mentioned above - the League of Polish Families, Self-Defence and the Real Politics Union - are also expressly homophobic. A politician from the first party, Roman Giertych, "led a public attack on the rights of sexual minorities, particularly in schools" (O’Dwyer \& Schwartz, 2010, p. 225) as Minister of Education (2006-2007). The discourse this party uses against the EU and sexual minorities should be considered populist, as it relies on "the highly selective use of facts, the biased or fallacious use of argument schemes and the hyperbolic or metaphoric exaggeration of facts $[\ldots]$ with the effect of arousing negative emotions (fear, anger, etc.) in mass audiences" (see the definition of populist right-wing discourse by Kienpointner, 2005, p. 218). Such discourse, being controversial or even scandalous, attracts more media attention than electorate, but this increased presence in the media might inaccurately suggest that it represents the majority's views.

All these aspects, next to working against the acceptance of sexual minorities, undermine the possibility of establishing a stronger, more stable, friendlier relationship with the European Union. The EU is too secular, too modern, too liberal. Cichocki writes that

emphasising the key role of Christian heritage for the strength of European identity is inconsistent with the post-Christian character of many Western European societies. Moreover, the tendency to make distant historic references might seem similarly eccentric, as EU integration has been rather based on forgetting than brooding on past events. (Cichocki, 2011, p. 267)

This quote illustrates exactly the incompatibility of Polish religious and traditional national narratives with values promoted by the EU. These issues may have been "overlooked" before accession, but after 2004, when "conditionality was weaker, domestic factors such as the perceived legitimacy and 'resonance' of the norms were crucial" (O'Dwyer \& Schwartz, 2010, p. 222). This means that there is, and will continue to be, a strong resistance to norms propagated by Brussels which are incompatible with national norms and values. In such a setting, LGBT become an embodiment of all that is wrong with modernization, and the EU is conceptualized as a space, symbolic and physical, from which all the dangers of modernization come from.

Thus, to the variables working to the disadvantage of LGBT in Polandreligion, national identity and the underdeveloped party system-we may add the underlying ideological tension between (post-)modern and conservative discourses: modernization versus tradition "elevated to a site of political struggle" 
(Sidorenko, 2008, p. 115), individualism versus collectivism, fragmentation and differentiation of identities versus the conservative efforts of reversing this fragmentation and restoring a stable dominant collective identity.

\section{Qualitative evidence}

\subsection{Advantages of discourse-oriented methods}

It has been suggested that opinion polls or surveys such as those discussed in Sections 2.1 and 2.3 may not offer the best method of eliciting attitudes towards various social groups, including minorities. In a study on surveying anti-Semitism in Poland, Winiewski and Bilewicz (2013) emphasize that various factors may influence the results of such surveys. They include framing of questions (e.g., the difference between using Jews or Jewish people may be significant) or the response format and range. Surveys and questionnaires often force respondents to adjust their opinions to a fixed matrix, for example a scale. People's opinions are usually rather vague and ambiguous, while such scales suggest that they are (or should be) definite, precise and explicit. Associated with this is the problem that even small changes in the formulation of questions may lead to major differences in answers (Potter \& Wetherell, 1987, p. 40).

The results may also be affected by the context of the study (incl. culture and norms, such as politeness or hospitability) and "the participants' inferences about who has conducted the survey and why" (Winiewski \& Bilewicz, 2013, p. 96). Also, many respondents would try to appear more liberal or open-minded than they actually are, especially when they suspect that the interviewer belongs to the minority in question or another (see the pollster effect in Winiewski \& Bliwicz, 2013, p. 94). Further, those "who feel they hold a minority opinion in society often tend to avoid saying what they really think" (Kovács, 2005, p. 272).

Last but not least,

self-contradictory answers within survey research often are regarded as threats to the reliability of the study rather than as signs of variation in the use of language. In opposition to this, variation and selfcontradictory answers are taken for granted in discursive psychology and such variations are seen as signs of the use of several discourses. (Jørgensen \& Phillips, 2002, p. 122; emphases by the author.)

This quote emphasizes the role played by variations and patterns of language use in everyday casual construction of attitudes. These variations comprise, 
for example, differing ways of defining the same concepts or using the same terms for different phenomena by competing discourses (cf. Chojnicka, 2013). A notorious example is referring to abortion as a 'murder of a conceived child' (zabójstwo dziecka poczętego) in conservative discourse and as an 'interruption of pregnancy' (przerwanie ciaży) in liberal and medical discourse. It is exactly the reason why relying on statistical data may be insufficient and should be complemented with qualitative illustrations provided by discourse analysis.

The usefulness of a discourse-oriented approach may be illustrated with the following example from a commentary to survey results:

Zakaz przeprowadzenia w Warszawie Parady Równości, a wcześniej podobne spory $w$ Krakowie pokazaty, że publiczne deklarowanie $i$ manifestowanie swojej orientacji homoseksualnej, a także dziatanie $w$ interesie tej grupy obywateli natrafia na opory znacznej części spoleczeństwa.

[The ban on organizing an Equality Parade in Warsaw, and earlier similar disputes in Cracow showed that public declaration and manifestation of one's sexual orientation, as well as activism in the interest of this group of citizens encounter resistance of a significant part of the society.] (CBOS, 2005, p. 5)

This interpretation is blatantly wrong, as the ban issued by Warsaw city authorities does not show resistance of any part of the society, just resistance of the ruling political elites. Such an "innocent mistake" is easy to miss and, when discovered, can always be explained as an unintended slip of the tongue. However, most of the time it goes unnoticed and the damage of representing the world in an incorrect, unjust, biased way is done.

Consider also the following examples of conservative Internet discourse, which, taken literally, seem to suggest that mothers are not alive and that feminists are not women:

Media o. Rydzyka bronia prof. Chazana: Nie mamy bronić praw matki, tylko życia.

[The media of rev. Rydzyk defend Prof. Chazan: We are not supposed to defend the rights of the mother, but of life.] (Gtos Rydzyka, 2014)

Od dawna widze, jak bardzo polskie feministki sa zainteresowane samymi soba, nie kobietami. 
[For a long time I've seen how much Polish feminists are only interested in themselves, not in women.] (Szczepkowska, 2014)

On the Internet, it is relatively simple to blame such mistakes on the characteristics of the medium - the requirement to publish in "real time", lack of proper editing, etc., if they are ever noticed.

The analysis of examples in the next section is thus supposed to illustrate and support the above claims. Countless studies have confirmed the usefulness of a discourse-oriented approach to, for example, collective identity (cf. Koller, 2012), radical ideology (cf. Musolff, 2008) or discursive out-group construction (Goodman, 2007). A previous article (Chojnicka, 2015) showed homophobic discourse as based mainly on arguments invoking family, nation and Church, the triad validated here.

\subsection{Example analysis}

An interesting example with which to start the analysis is the website www. naszawitryna.pl, described as "politically incorrect" on the start page. It has been created to expose activities aimed "against our country, our Nation, our identity and national pride" (przeciwko naszemu państwu, naszemu Narodowi, naszej tożsamości i dumie narodowej). The website clearly declares a nationalistic, Catholic and anti-European stance. It collects texts from other sources grouped into several categories, such as 'Anti-Catholicism' (Antykatolicyzm), 'PolishJewish Dialogue' (Dialog polsko-żydowski), 'Crimes on Poles' (Zbrodnie na Polakach) or 'No to the EU' (Nie dla UE).

Under the address www.naszawitryna.pl/haslo.html, one may find Eurosceptic slogans created by Polish Internet users before the EU accession, in a kind of mock reaction to the contest for the best pro-European slogan announced by the political party Unia Wolności ('Freedom Union'). Altogether 216 listed slogans associate the European Union mostly with (1) homosexuals, paedophilia, abortion and euthanasia, promiscuity and sexually transmitted diseases ${ }^{2} ;(2)$ Soviet Union and Nazi Germany; (3) Jews (many examples of anti-Semitism); (4) the loss of Polish sovereignty; and (5) financial concerns (e.g., the high costs

2 Together, these phenomena constitute the "civilization of death", which is a term first used by Pope Jean Paul II and now widely employed for persuasive/propaganda purposes by conservative speakers in Poland when arguing against homosexuality, abortion, in vitro fertilization, etc. 
of membership, more competition on the market). Some examples follow (the spelling of the Polish examples has been corrected where necessary):

1) Nie masz z czego żyć? Unia ci pomoże-eutanazja czeka na ciebie. [You have nothing to live on? The Union will help you-euthanasia awaits you.]

2) Unia Eurpoejska -Ein Volk, Ein Reich, Ein Fuhrer (original spelling)

3) Żydzi się ciesza - cieszmy się i my. Wybierz Unię! [The Jews are rejoicing — let us rejoice too. Choose the Union!]

4) Chcesz do UE? Wyrywaj tam już dzisiaj. Polskę zostaw w spokoju. [You want to [go to] the EU? Run there already today. Leave Poland alone.]

5) Niech żyje Unia Europejska! Ale na wtasny koszt. [Long live the European Union! But at its own expense.]

In slogans of the fourth type, a clear and strong dissociation of Poland from the European Union - but not from Europe (consider Example 7 below) - is visible. The EU is conceptualized as a distant and foreign space, both in physical and symbolic terms. Furthermore, Poland and the EU are presented as mutually exclusive poles of a binary system as voting against the EU means "choosing" Poland, voting for the EU means leaving/betraying Poland:

6) Zapomnij o Polsce! Wybierz Unię!

[Forget Poland! Choose the Union!]

7) Europa-tak, Unia Europejska-nie.

[Europe-yes, the European Union-no.]

8) Jak nie Unia, to co? Polska, sukinsynie, Polska!

[If not the Union, then what? Poland, son of the bitch, Poland!]

The next example illustrates a reference to homosexuality in an anti-EU slogan:

9) Bezdzietne malżeństwo dwóch tatusiów czeka już w Unii na Twojego syna.

[A childless married couple of two daddies is already waiting in the Union for your son.]

This sentence clearly exploits one of the most common stereotypes about homosexuality - that it equates paedophilia. It thus plays on the feelings of parents worried about their children's health and safety, even if it remains unclear why a childless married couple elsewhere in the EU should adopt(?) someone else's son. The slogan thus uses a powerful symbol at the disposal of conservative discourse - that of the family. Family is a strong value, but at the same time appears vulnerable, in danger and in need of protection. 
Homosexuality is often equated not only with paedophilia, but also, for example, zoophilia:

10) Pedofile, pederaści to sa euroentuzjaści.

[Paedophiles, pederasts are Euro-enthusiasts.]

11) Chcesz wywalczyć prawo do wspótżycia ze swoją suka - głosuj na UE. [You want to achieve the right to have relations with your bitch [dog]? Vote for the EU!]

12) Bruksela to nie same pedaly, sa jeszcze lesbijki, pedofile, nekrofile i inni "normalni ludzie".

[Brussels is not only homos, there are also lesbians, paedophiles, necrophiles and other "normal people".]

These examples paint a picture of the degenerate West opposed to Poland as an outpost of normalcy. They also suggest that homosexuality is as distant, foreign and un-Polish as the European Union itself. This allows to conflate the EU and sexual minorities, even if it leads to a nonsensical conclusion that everyone in the EU is gay, and every gay comes from the EU.

Similar motives show up in the analysis of material published after the accession:

13) Moje zdanie jest takie, że trza się wypisywać z tego pedalsko pedofilskiego cyrku jak najszybciej.

[My opinion is such, that [we] must sign out of this homo-paedophile circus as fast as possible.]

Such statements build upon a common misconception about homosexuality (and promiscuity) originating in the European Union, both in terms of time and space. In terms of the former, conservative discourse holds that there used to be no homosexuality in Poland at all before it joined the EU (even though it undermines the EU equals USSR argument). When it comes to the latter, the argument goes that homosexuality is not reconcilable with what it means to be Polish. Thus, it must be a foreign "invention". Both arguments are fallacious-in the past, homosexuality was just not visible due to the climate of legal and social restrictions; and the present proliferation of sexual discourses and promiscuous lifestyles is attributable to global processes of modernization and social change rather than membership in the EU. Even more so, they seem to implicate that leaving the EU would also "solve" the issues of homosexuality, paedophilia and promiscuity.

The following example illustrates the already mentioned comparison of the European Union with communism and the Soviet Union: 
14) unia dyskryminuje ludzi normalnie myslacych popiera obrzydliwe zboczenia [...] precz z unia komuchami i pedalami

[the Union discriminates against normally thinking people supports disgusting perversions $[\ldots]$ away with the Union communists and homos.]

Comparing the European Union with its inclusive, affirmative policy to the Soviet Union, where homosexuality was a criminal offence, is baffling. Still, such associations abound on the Internet.

Further, as the following example illustrates, the EU's liberal policies are not always understood as consciously planned and deliberate. Next to the popular conspiracy theory (whereby making everyone gay in order to reduce the human population is a conscious project of the EU), there exists also a theory according to which the EU simply does not see how harmful and dangerous its actions are. This is only something that conservative, traditional societies can see because they are not "blinded" by a total lack of norms, rules and discipline.

\section{5) Przecież widać to, jak na dłoni, że "postępowa” Europa zmierza do samounicestwienia. \\ [It is as clear as day that the "progressive" Europe is aiming for self- destruction.]}

The next example expresses the widespread fear for the family and its survival. It also loosely refers to the "Poland as an island of normalcy" idea mentioned above. The phrase nie dajmy sie zwariować - the verb zwariować literally meaning 'to go crazy', 'to go mad'-implies imminent danger, not only to the family but also to the mental health of the island's survivors.

16) Nie dajmy się zwariować niszczycielom naszych rodzin i tym oszołomom politycznie i unijnie poprawnym!!!

[Let's not allow the destroyers of our families and those politically and unionistically correct fanatics make us crazy!!!]

These examples show that contemporary Polish conservative discourse not only embraces Euroscepticism and prejudice against LGBT. It also, as it were, conflates sexual minorities with the EU, rejecting the possibility that homosexuality existed in this country before or that it has always pertained to a certain proportion of its population, just as in any other country on Earth. Homosexuality is incompatible with the Polish identity, thus it must be a modern invention (in terms of timetemporal distanciation) and something foreign, distant (in terms of space- - spatial distanciation). Tolerance and acceptance of homosexuality, as well as the inclusion 
of LGBT rights into the state-level legal frameworks, are seen as obligations imposed from outside and above (i.e. from Brussels), rather than originating from the inside and below (i.e. the popular will).

Through the association of homosexuality with "civilization of death", Eurosceptics employ the liberal stance of the EU on LGBT issues in order to "prove" that the Union is heading for a disaster. On the other hand, homophobes operationalize the claim that pro-gay norms come from Brussels to argue that they are foreign to and incompatible with the local way of life. This way, Eurosceptic and homophobic discourses reinforce each other.

It must be noted that although the examples analyzed above may lead one to a conclusion that Poles are highly intolerant, prejudiced and xenophobic, it must be kept in mind that they do not reflect the views of all of them. As data in Section 2 shows, the Polish society is divided when it comes to the issues of LGBT rights and assessment of the European Union. The conservative discourse investigated here, including radical right-wing discourse, represents only one side of this debate. Qualitative research like discourse analysis does not represent the scope or extent of the attitudes analyzed; however, it gives us an idea of their nature and characteristics, and helps problematize and critically address the most extreme or radical ones instead of averaging them out.

\section{Discussion and conclusion}

A recent report by the Heinrich Böll Foundation on anti-gender movements (that include anti-feminist and anti-LGBT movements) in Central and Eastern Europe suggests that the rise in anti-emancipation activism is a "wider, at least regional trend",

consisting of right-wing populists, ultra-nationalist extremists, and anti-egalitarian movements (frequently anti-immigrant as well as anti-feminist), which are worming their way into public discourse. Unfortunately, such movements are pushing the political establishment of many (Eastern) European countries towards accommodation, pretending - as all populists do - that they represent society at large. (Heinrich Böll Foundation, 2015, p. 9)

Similarly, Torreblanca and Leonard (2013, p. 1) write that Euroscepticism, no longer seen as a mainly British phenomenon, is now "spreading across the continent like a virus". Boros and Vasali $(2013$, p. 1) agree that "negative 
attitudes towards the European Union have been on the rise in the majority of European societies". Poland is thus not exceptional in harbouring both anti-EU and anti-LGBT sentiments and should be seen as one of the possible case studies exemplifying a more general phenomenon.

Even more so, the report of the Heinrich Böll Foundation introduced above supports both claims made in the present article:

1) In theoretical-methodological terms, it indicates the importance of both quantitative and qualitative methods in understanding, examining and explaining anti-Europeanization and anti-emancipation attitudes. The chapters devoted to different countries offer both statistical information and more indepth analyses of specific events that illustrate the general anti-gender trends. The fragment quoted above also emphasizes the significance of the discursive approach as a particular qualitative methodology. Public discourse, especially that of mainstream media and the political field, has the ability to impose attitudes on the society while creating an impression of being representative of its interests and opinions (van Dijk, 1997). Critical analysis of public discourse thus makes it possible to predict a rise in specific attitudes or social movements before they can be reflected in public opinion polls and other statistical formats.

2) The second claim made in this article, supported by the Foundation's report (although only partly, i.e. not by all authors of separate chapters), is the hypothesis that the anti-gender movements analyzed have a more general, underlying reason. Graff suggests that the gradual process of reducing the rights of women and sexual minorities which has been taking place in Poland for over a decade now should not be seen as a result of a conservative conspiracy or a weakness of emancipatory movements, but rather as a side-effect of social tension or cultural anxiety experienced by many people (Graff, 2010, p. 125), who mitigate or deal with this anxiety by resorting to de-traditionalization (Fodor \& Balogh, 2010). Tradition is thus promoted over equality, and the European Union is seen as a "place of moral decline" (Heinrich Böll Foundation, 2015, p. 7).

Sexual minorities are the most visible and controversial symbol of such social movements and shifts as feminism, sexual freedom, sexuality (understood in terms of pleasure rather than procreation), alternative sexual and gender identities, etc. And these, in turn, undermine and threaten the traditional understandings of gender roles, marriage, family, masculinity and femininity. Sexual minorities thus symbolize changes which are often threatening and difficult to accept; they embody all that is wrong with modernization. 
The European Union, for its part, embraces and promotes (but not exactly creates or invents) these very changes. In such a context, the EU is conceptualized as a space, symbolic and physical, from which all the dangers of modernization come from. LGBT people can easily be hated because they are a "European invention" as they do not belong to the in-group of the traditional (Polish) nation; and Europe can be hated because it lets the LGBT people in. That is, in short, how the anti-EU and anti-LGBT discourses reinforce each other. Euroscepticism and LGBT prejudices are thus not just occasionally, coincidentally connected expressions of an underlying resistance to change. Moreover, it is possible to hypothesize that much of the Eurosceptic and homophobic discourse is not really about the European Union or sexual minorities per se: it is about losing the stability of a given, fixed, unchangeable collective identity.

One question remains unsolved: where does this fear of social and cultural change come from? Why is change so terrifying in the first place?

Could it be possible that this fear is caused by a deeply hidden, repressed doubt in the success of democratic transition? Could it be the terror of discovering that the neoliberal world is not perfect after all? Could it be the impossibility of admitting that this grand, supreme (and narcissistic) nation... has been wrong?

Homophobia is sometimes explained as a fear caused by one's own deep-hidden homosexual attraction. Since Polish right-wing discourse insists on comparing the European Union to the Soviet Union, maybe Euroscepticism can be explained as a fear caused by one's own suspicion that capitalism is not any better than socialism after all?

Joanna Chojnicka is postdoctoral fellow at the Zukunftskolleg, University of Konstanz (2013-2015), and a postdoctoral researcher at the Faculty of Linguistics and Literary Studies of the University of Bremen since December 2015. She is also an associate fellow at the Herder Institute in Marburg and lecturer at the Leuphana University in Lüneburg. Having studied in Poland, Latvia, Lithuania and Germany, she obtained her doctorate in linguistics in 2012 at the Adam Mickiewicz University in Poznań, Poland. Her recent research interests include gender and sexuality issues in Central and Eastern Europe from the perspective of critical discourse analysis and critical language awareness. 


\section{References}

Abramowicz, M. (2010), 'Sytuacja społeczna osób bi- i homoseksualnych w Polsce,' in J. Kochanowski, M. Abramowicz \& R. Biedroń (eds.) Queer Studies: Podręcznik kursu, Warszawa: Kampania Przeciw Homofobii, pp. 97-114.

Adamiak, E. \& Sobkowiak, S. (2011), 'Gender and religion in Central and Eastern Europe: Theoretical approaches,' European Journal of Mental Health, vol. 6, pp. 3-25. http://dx.doi.org/10.5708/EJMH.6.2011.1.1

Bertelsmann Stiftung (2013), Social Cohesion Radar: Measuring Common Ground, Gütersloh: Bertelsmann Stiftung.

Boros, T. \& Vasali, Z. (2013), The Rise of Euroskepticism and Possible Responses prior to the 2014 European Parliament Elections, Brussels: Foundation for European Progressive Studies.

Caliendo, G. \& Magistro, E. (2009), 'The human face of the European Union: A critical study,' Critical Approaches to Discourse Analysis across Disciplines, vol. 3, no. 2, pp. 176-202.

CBOS (2001), Postawy wobec matżeństw homoseksualistów, Warszawa: CBOS.

— (2003), Związi partnerskie par homoseksualnych, Warszawa: CBOS.

— (2005), Akceptacja praw dla gejów i lesbijek i społeczny dystans wobec nich, Warszawa: CBOS.

- (2008), Prawa gejów i lesbijek, Warszawa: CBOS.

— (2010), Postawy wobec gejów i lesbijek, Warszawa: CBOS.

_ (2013), Stosunek do praw gejów i lesbijek oraz związów partnerskich, Warszawa: CBOS.

Chojnicka, J. (2013), 'Nazis vs. occupants: the language of ethnic conflict in Latvian parliamentary debates,' Journal of Language Aggression and Conflict, vol. 1, no. 2, pp. 225-255.

(2015), 'Homophobic speech in post-socialist media: A preliminary typology of homophobic manipulative discourse,' The Journal of Language and Sexuality, vol. 4, no. 1, pp. 139-174. http://dx.doi.org/10.1075/jls.4.1.05cho

Cichocki, P. (2011), 'Polish attitudes towards the European Union,' Przeglad Zachodni, no. 3, pp. 265-277.

Duvold, K. \& Aalia, I. (2012), 'Fear and Loathing in Lithuania,' Baltic Worlds, no. 2, pp. $40-47$.

$\mathrm{EC}=$ European Commission (2004), Standard Eurobarometer 62, Brussels: European Commission. Retrieved from http://ec.europa.eu/public_opinion/archives/eb/eb62/ eb62_en.htm [accessed 25 Mar 2014]

_ (2005a), Standard Eurobarometer 63, Brussels: European Commission. Retrieved from http://ec.europa.eu/public_opinion/archives/eb/eb63/eb63_en.htm [accessed 25 Mar 2014] 
(2005b), Standard Eurobarometer 64, Brussels: European Commission. Retrieved from http://ec.europa.eu/public_opinion/archives/eb/eb64/eb64_en.htm [accessed 25 Mar 2014]

(2006a), Standard Eurobarometer 65, Brussels: European Commission. Retrieved from http://ec.europa.eu/public_opinion/archives/eb/eb65/eb65_en.htm [accessed 25 Mar 2014]

(2006b), Standard Eurobarometer 66, Brussels: European Commission. Retrieved from http://ec.europa.eu/public_opinion/archives/eb/eb66/eb66_en.htm [accessed 25 Mar 2014]

— (2007a), Standard Eurobarometer 67, Brussels: European Commission. Retrieved from http://ec.europa.eu/public_opinion/archives/eb/eb67/eb67_en.htm [accessed 25 Mar 2014]

— (2007b), Standard Eurobarometer 68, Brussels: European Commission. Retrieved from http://ec.europa.eu/public_opinion/archives/eb/eb68/eb68_en.htm [accessed 25 Mar 2014]

— (2007c), Discrimination in the European Union. Special Eurobarometer 263, Brussels: European Commission. Retrieved from http://ec.europa.eu/public_opinion/ archives/ebs/ebs_263_en.pdf [accessed 25 Mar 2014]

(2008a), Standard Eurobarometer 69, Brussels: European Commission. Retrieved from http://ec.europa.eu/public_opinion/archives/eb/eb69/eb69_en.htm [accessed 25 Mar 2014]

— (2008b), Standard Eurobarometer 70, Brussels: European Commission. Retrieved from http://ec.europa.eu/public_opinion/archives/eb/eb70/eb70_en.htm [accessed 25 Mar 2014]

(2008c), Discrimination in the European Union: Perceptions, Experiences and Attitudes. Special Eurobarometer 296, Brussels: European Commission. Retrieved from http://ec.europa.eu/public_opinion/archives/ebs/ebs_296_en.pdf [accessed 25 Mar 2014]

(2009a), Standard Eurobarometer 71, Brussels: European Commission. Retrieved from http://ec.europa.eu/public_opinion/archives/eb/eb71/eb71_en.htm [accessed 25 Mar 2014]

— (2009b), Standard Eurobarometer 72, Brussels: European Commission. Retrieved from http://ec.europa.eu/public_opinion/archives/eb/eb72/eb72_en.htm [accessed 25 Mar 2014]

— (2009c), Discrimination in the EU in 2009. Special Eurobarometer 317, Brussels: European Commission. Retrieved from http://ec.europa.eu/public_opinion/ archives/ebs/ebs_317_en.pdf [accessed 25 Mar 2014]

(2010a), Standard Eurobarometer 73, Brussels: European Commission. Retrieved from http://ec.europa.eu/public_opinion/archives/eb/eb73/eb73_en.htm [accessed 25 Mar 2014] 
(2010b), Standard Eurobarometer 74, Brussels: European Commission. Retrieved from http://ec.europa.eu/public_opinion/archives/eb/eb74/eb74_en.htm [accessed 25 Mar 2014]

(2011a), Standard Eurobarometer 75, Brussels: European Commission. Retrieved from http://ec.europa.eu/public_opinion/archives/eb/eb75/eb75_en.htm [accessed 25 Mar 2014]

(2011b), Standard Eurobarometer 76, Brussels: European Commission. Retrieved from http://ec.europa.eu/public_opinion/archives/eb/eb76/eb76_en.htm [accessed 25 Mar 2014]

_ (2012a), Standard Eurobarometer 77, Brussels: European Commission. Retrieved from http://ec.europa.eu/public_opinion/archives/eb/eb77/eb77_en.htm [accessed 25 Mar 2014]

— (2012b), Standard Eurobarometer 78, Brussels: European Commission. Retrieved from http://ec.europa.eu/public_opinion/archives/eb/eb78/eb78_en.htm [accessed 25 Mar 2014]

— (2012c), Discrimination in the EU in 2012. Special Eurobarometer 393, Brussels: European Commission. Retrieved from http://ec.europa.eu/public_opinion/ archives/ebs/ebs_393_en.pdf [accessed 25 Mar 2014]

(2013a), Standard Eurobarometer 79, Brussels: European Commission. Retrieved from http://ec.europa.eu/public_opinion/archives/eb/eb79/eb79_en.htm [accessed 25 Mar 2014]

— (2013b), Standard Eurobarometer 80, Brussels: European Commission. Retrieved from http://ec.europa.eu/public_opinion/archives/eb/eb80/eb80_en.htm [accessed 25 Mar 2014]

Fodor, É. \& Balogh, A. (2010), 'Back to the kitchen? Gender role attitudes in 13 East European countries,' Zeitschrift für Familienforschung (Journal of Family Research), vol. 22, no. 3, pp. 289-307.

Głos Rydzyka (2014), 'Media o. Rydzyka bronią prof. Chazana: Nie mamy bronić praw matki, tylko życia,' [Blog entry] Głos Rydzyka. Retrieved from http://glosrydzyka. blox.pl/2014/06/Media-o-Rydzyka-bronia-prof-Chazana-Nie-mamy.html [accessed 11 Aug 2014]

Goodman, S. (2007), 'Constructing asylum seeking families,' Critical Approaches to Discourse Analysis across Disciplines, vol. 1, no. 1, pp. 36-50.

Graff, A. (2006), 'We are (not all) homophobes - a report from Poland,' Feminist Studies, vol. 32, no. 2, pp. 434-449.

(2010), 'Niebezpieczne związki, czyli: gender - seksualność - naród,' in J. Kochanowski, M. Abramowicz \& R. Biedroń (eds.) Queer studies: Podręcznik kursu, Warszawa: Kampania Przeciw Homofobii, pp. 125-137.

Gruszczyńska, A. (2007), 'Living 'la vida' Internet: Some notes on the cyberization of Polish LGBT community,' in R. Kuhar \& J. Takács (eds.) Beyond the Pink Curtain. 
Everyday Life of LGBT People in Eastern Europe, Ljubljana: Mirovni Institut / Peace Institute, pp. 95-115.

Heinrich Böll Foundation (2015), Anti-Gender Movements on the Rise? Strategising for Gender Equality in Central and Eastern Europe, Publication Series on Democracy, vol. 38, Berlin: Heinrich Böll Foundation.

Jørgensen, M. \& Phillips, L. (2002), Discourse Analysis as Theory and Method, London: Sage Publications.

Kienpointner, M. (2005), 'Racist manipulation within Austrian, German, Dutch, French and Italian right-wing populism,' in L. de Saussure \& P. Schulz (eds.) Manipulation and Ideologies in the Twentieth Century, Amsterdam \& Philadelphia: John Benjamins, pp. 213-236.

Koller, V. (2012), 'How to analyse collective identity in discourse - textual and contextual parameters,' Critical Approaches to Discourse Analysis across Disciplines, vol. 5, no. 2, pp. 19-38.

Kovács, A. (2005), 'The role of a political identity code in defining the boundaries of public and private: The example of latent antisemitism,' in R. Wodak \& P. Chilton (eds.) A New Agenda in (Critical) Discourse Analysis, Amsterdam \& Philadelphia: John Benjamins, pp. 269-281.

Lindqvist, B. (2003), 'An arena for contested identities. National identity and ethnic diversity at Latvian schools,' in M. Lindqvist (ed.) Re-inventing the Nation: Multidisciplinary Perspectives on the Construction of Latvian National Identity, Botkyrka: Multicultural Centre, pp. 293-350.

Magistro, E. (2007), 'Promoting the European identity: Politeness strategies in the discourse of the European Union,' Critical Approaches to Discourse Analysis across Disciplines, vol. 1, no. 1, pp. 51-73.

Marody, M. \& Mandes, S. (2005), 'On function of religion in molding the national identity of Poles,' International Journal of Sociology, vol. 35, no. 4, pp. 49-68.

McManus-Czubińska, C. \& Miller, W. (2008), "European civilisation or European civilisations: the EU as a 'Christian club'?” in M. Myant \& T. Cox (eds.) Reinventing Poland: Economic and political transformation and evolving national identity, London: Routledge, pp. 128-149.

Mishler, W. \& Pollack, D. (2003), 'On culture, thick and thin: Toward a neo-cultural synthesis,' in D. Pollack, J. Jacobs, O. Muller \& G. Pickel (eds.) Political Culture in Post-Communist Europe: Attitudes in New Democracies, Aldershot: Ashgate, pp. 237-256.

Mole, R. C. M. (2012), The Baltic States from the Soviet Union to the European Union: identity, discourse and power in the post-communist transition of Estonia, Latvia and Lithuania, London: Routledge.

Mostov, J. (2000), 'Sexing the nation/desexing the body. Politics of national identity in the former Yugoslavia,' in T. Mayer (ed.) Gender Ironies of Nationalism: Sexing the Nation, London: Routledge, pp. 89-112. 
Musolff, A. (2008), 'What can critical metaphor analysis add to the understanding of racist ideology? Recent studies of Hitler's anti-Semitic metaphors,' Critical Approaches to Discourse Analysis across Disciplines, vol. 2, no. 2, pp. 1-10.

O'Dwyer, C. \& Schwartz, K. Z. S. (2010), 'Minority rights after EU enlargement: A comparison of antigay politics in Poland and Latvia,' Comparative European Politics, vol. 8, no. 2, pp. 220-243. http://dx.doi.org/10.1057/cep.2008.31

Potter, J. \& Wetherell, M. (1987), Discourse and Social Psychology: Beyond Attitudes and Behaviour, London: Sage Publications.

Rient, R. (n.d.), 'Geje są leniwymi, tęczowymi lemingami: wolą siedzieć w szafie niż upomnieć się o swoje prawa,' [Blog entry], naTemat.pl. Retrieved from http://natemat.pl/41793, geje-sa-leniwymi-teczowymi-lemingami-wola-siedziec-w-szafieniz-upomniec-sie-o-swoje-prawa [accessed 23 Apr 2014]

Schröder, I. W. (2009), 'Hegemonic narratives and religious identity politics in contemporary Lithuania,' Acta Historica Universitatis Klaipedensis, XIX, Studia Anthropologica, vol. III, pp. 49-57.

Selinger, M. (2008), 'Intolerance towards gays and lesbians in Poland,' Human Rights Review, vol. 9, no. 1, pp. 15-27. http://dx.doi.org/10.1007/s12142-007-0026-2

Sidorenko, E. (2008), 'Which way to Poland? Re-emerging from Romantic unity,' in M. Myant \& T. Cox (eds.) Reinventing Poland: Economic and political transformation and evolving national identity, London: Routledge, pp. 109-127.

Szczepkowska, J. (2014), 'Szczepkowska dla Fronda.pl: Idę własną drogą,' Fronda. pl. Retrieved from http://www.fronda.pl/a/szczepkowska-dla-frondapl-ide-wlasnadroga,38510.html [accessed 11 Aug 2014]

Torreblanca, J. I. \& Leonard, M. (2013), The Continent-wide Rise of Euroscepticism, Berlin: European Council on Foreign Relations.

van Dijk, T. A. (1983), 'Discourse analysis: Its development and application to the structure of news,' Journal of Communication, vol. 33, no. 2, pp. 20-43. (1993), 'Principles of critical discourse analysis,' Discourse \& Society, vol. 4, no. 2, pp. 249-283. http://dx.doi.org/10.1177/0957926593004002006 (1997), 'What is political discourse analysis?' in J. Blommaert \& C. Bulcaen (eds.) Political Linguistics, Amsterdam: John Benjamins, pp. 159-177.

Winiewski, M. \& Bilewicz, M. (2013), 'Are surveys and opinion polls always a valid tool to assess anti-Semitism? Methodological considerations,' Jewish Studies at the CEU, vol. 7, pp. 83-97.

Wodak, R. (2002), 'Aspects of Critical Discourse Analysis,' Zeitschrift für Angewandte Linguistik, no. 36, pp. 5-31. 